\title{
Pasteurization of milk: The heat inactivation kinetics of milk-borne dairy pathogens under commercial-type conditions of turbulent flow
}

\author{
L. E. Pearce,${ }^{\star 1}$ B. W. Smythe,${ }^{*}$ R. A. Crawford,† E. Oakley,‡ S. C. Hathaway,§ and J. M. Shepherd ${ }^{\star}$ \\ ${ }^{*}$ Fonterra Research Centre, Dairy Farm Road, Private Bag 11029, Palmerston North, New Zealand \\ †Fonterra (Te Rapa), PO Box 10397, State Highway 1, Te Rapa, Hamilton, New Zealand \\ fMAF Biosecurity New Zealand, PO Box 2526, 25 The Terrace, Wellington, New Zealand \\ $\S N e w$ Zealand Ministry of Agriculture and Forestry, PO Box 2835, 68-86 Jervois Quay, Wellington, New Zealand
}

\section{ABSTRACT}

This is the first study to report kinetic data on the survival of a range of significant milk-borne pathogens under commercial-type pasteurization conditions. The most heat-resistant strain of each of the milk-borne pathogens Staphylococcus aureus, Yersinia enterocolitica, pathogenic Escherichia coli, Cronobacter sakazakii (formerly known as Enterobacter sakazakii), Listeria monocytogenes, and Salmonella was selected to obtain the worst-case scenario in heat inactivation trials using a pilot-plant-scale pasteurizer. Initially, approximately 30 of each species were screened using a submerged coil unit. Then, UHT milk was inoculated with the most heat-resistant pathogens at $\sim 10^{7} / \mathrm{mL}$ and heat treated in a pilot-plant-scale pasteurizer under commercial-type conditions of turbulent flow for $15 \mathrm{~s}$ over a temperature range from 56 to $66^{\circ} \mathrm{C}$ and at $72^{\circ} \mathrm{C}$. Survivors were enumerated on nonselective media chosen for the highest efficiency of plating of heat-damaged bacteria of each of the chosen strains. The mean $\log _{10}$ reductions and temperatures of inactivation of the 6 pathogens during a 15 -s treatment were Staph. aureus $>6.7$ at $66.5^{\circ} \mathrm{C}, Y$. enterocolitica $>6.8$ at $62.5^{\circ} \mathrm{C}$, pathogenic $E$. coli $>6.8$ at $65^{\circ} \mathrm{C}$, C. sakazakii $>6.7$ at $67.5^{\circ} \mathrm{C}$, L. monocytogenes $>6.9$ at $65.5^{\circ} \mathrm{C}$, and Salmonella ser. Typhimurium $>6.9$ at $61.5^{\circ} \mathrm{C}$. The kinetic data from these experiments will be used by the New Zealand Ministry of Agriculture and Forestry to populate the quantitative risk assessment model being developed to investigate the risks to New Zealand consumers from pasteurized, compared with nonpasteurized, milk and milk products.

Key words: milk pasteurization, heat inactivation, kinetics, dairy pathogen

\footnotetext{
Received May 20, 2011.

Accepted September 2, 2011.

${ }^{1}$ Deceased March 1, 2010; manuscript submitted posthumously from senior author's notes. Correspondence should be sent to Justin Bendall (justin.bendall@fonterra.com).
}

\section{INTRODUCTION}

In recent years, a paradigm shift has taken place in the regulatory approach to food safety. The emphasis has changed from prescribing in detail the processes that must be used, to defining the desired outcomes for human health, hazard control, or both, and to providing flexibility to industry as to how it may achieve these outcomes. This philosophy centers on risk-based approaches and has been adopted internationally by the Codex Alimentarius Commission (1997) and nationally by standard-setting agencies. One such agency, the New Zealand Ministry of Agriculture and Forestry, is developing a quantitative risk assessment (QRA) model to assess the risk to New Zealand consumers from consuming bovine milk and milk products (Oakley et al., 2007).

The change from a prescriptive, process-based approach to the risk-based approach to food safety regulation has exposed a huge gap between what is known about the heat sensitivity of milk-borne pathogens and the quantitative kinetic data that are now required. Reliable data on the effectiveness of pasteurization at destroying key milk-borne pathogens are essential for this modeling. Such data have not hitherto been available.

Piyasena and coworkers (1998) demonstrated the importance of using commercial-type conditions with turbulent flow in pasteurization experiments. They pointed out that batch processes cannot be readily extrapolated to continuous HTST pasteurization as they do not take into account shear force and other physical stress. In their work, a minimum $11 \log _{10}$ kill of Listeria monocytogenes at $72^{\circ} \mathrm{C} / 15 \mathrm{~s}$ was calculated, suggesting that commercial-type pasteurization with turbulent flow was much more effective than laboratory studies would have indicated. A kinetic study of the heat inactivation of Mycobacterium avium ssp. paratuberculosis (MAP) emphasized the importance of turbulent flow in a pasteurizer (Pearce et al., 2001). The calculated $72^{\circ} \mathrm{C} / 15 \mathrm{~s}$ heat inactivation for the type strain and 4 other MAP strains was at least $7 \log _{10}$. This was per- 
haps not surprising as current pasteurization conditions have long been known to provide a very high margin of safety for the highly heat-resistant pathogen Mycobacterium bovis (Kells and Lear, 1960; Pearce, 2002).

In contrast, an earlier review of the heat inactivation of L. monocytogenes in milk and other media had concluded, based on small-scale laboratory experiments, that pasteurization achieved only a mean $5.2 \log _{10}$ destruction of L. monocytogenes (Mackey and Bratchell, 1989). However, considerable variability can be inherent in laboratory heat inactivation experiments. For example, a comparison of results for MAP showed that, when 5 different laboratory pasteurization procedures were compared, heat inactivation ranged from less than $1 \log _{10}$ to greater than $6 \log _{10}$ reduction. This was despite all of these studies using the type strain of MAP and the same time-temperature conditions (Pearce, 2004). A given laboratory heating method will not necessarily predict actual commercial-type HTST pasteurization results. However, some methods, if well controlled, are adequately reproducible and hence are useful for comparing relative heat resistances between strains.

Previously reported MAP heat inactivation experiments (Pearce et al., 2001) provided valuable insights into the methodology required to obtain inactivation data under commercial-type conditions in a turbulentflow pasteurizer. The same basic equipment was used in a joint project initiated with the New Zealand Ministry of Agriculture and Forestry to obtain heat inactivation data on milk-borne pathogens for the QRA model. Some equipment modification was necessary to provide a level 2 physical containment (PC2) operating environment, and strains that could be safely handled under these conditions were chosen.

The aim of this work was to fill the above-mentioned pasteurization data gap with robust kinetic data collected from a standardized, repeatable, practical, safe, and cost-effective protocol for modeling the heat inactivation of various non-spore-forming pathogens from raw milk on a commercial-type scale. Although batch (vat) pasteurization still has a role for smaller cheese producers, this study considered HTST pasteurization exclusively because it is the only form of pasteurization used by any of Fonterra's industrial-scale manufacturing operations. The 6 milk-associated bacterial pathogens selected for this initial study all have significance for public health and are likely to be recoverable from raw milk. That makes this study of practical value to regulatory authorities and dairy product manufacturers alike. Moreover, the 6 pathogens could all be used safely in appropriate $\mathrm{PC} 2$ facilities. In future, other pathogens may be examined using the protocol described herein, along with any new emerging dairy pathogens.
Two important pathogens not included in this study were Coxiella burnetii and Mycobacterium tuberculosis, which are currently recognized as being the most heatresistant non-spore-forming pathogens in raw milk and, as such, form part of the Codex Alimentarius (2004) definition of milk pasteurization. Coxiella burnetii was also important during the historical establishment of time-temperature combinations for producing safe pasteurized milk (Cerf and Condron, 2006). However, those severely hazardous bacterial pathogens would have required containment in $\mathrm{PC} 3$ facilities at prohibitive cost. Furthermore, as New Zealand is officially free of Coxiella burnetii, importing that organism into New Zealand for this study would have created a biosecurity risk.

\section{MATERIALS AND METHODS}

The protocol adopted followed recommendations made by the International Dairy Federation International Workshop on Heat Resistance of Pathogenic Organisms (McClure et al., 2004). These included choice of strains, single strain versus a cocktail, culture maintenance and inoculum preparation, choice of heating menstruum, heating apparatus and treatment, recovery methods, access to raw data, and statistical analyses. In addition to these elements, unique components of the heat inactivation protocol adopted were the use of a laboratory system to select the most heat-resistant strain from 30 representatives of each of the pathogenic groups, the use of a turbulent-flow, pilot-plantscale pasteurizer to obtain kinetic data to determine $D$-values [the time taken, at a given temperature, to achieve a 10-fold (or decimal) decrease in the number of viable organisms] and $z$-values (the temperature change required to give a 10 -fold change in the $D$-value) of the chosen strains, and the use of nonselective recovery media to give the highest efficiency of plating of survivors.

\section{Bacterial Strains}

Panels of approximately 30 strains representing each of 6 milk-associated bacterial pathogens (Staphylococcus aureus, Yersinia enterocolitica, pathogenic Escherichia coli, Cronobacter sakazakii, Listeria monocytogenes, and Salmonella serotypes) were assembled (Table 1). Where applicable, pathogenic and nonpathogenic isolates from dairy environments or dairy products, bovine and raw milk isolates, type strains, nonpathogenic surrogates, and known different genetic groupings were included in the panels. In some cases, related species that were suspected as being pathogenic were included in the panel, even if pathogenicity had not been established. For example, single isolates of Citrobacter koseri and Enterobacter cloacae were included with C. sakazakii. 
PEARCE ET AL.

Table 1. Strain number, name, origin, and submerged coil unit heat sensitivity of pathogen isolates

\begin{tabular}{|c|c|c|c|c|}
\hline $\begin{array}{l}\text { Species/ } \\
\text { strain no. }\end{array}$ & $\begin{array}{l}\text { Salmonella } \\
\text { serotypes }\end{array}$ & Strain $^{1}$ & Origin & $\begin{array}{l}\log \\
\text { reduction }\end{array}$ \\
\hline \multicolumn{5}{|c|}{ Staphylococcus aureus } \\
\hline 1 & & FRI 326 & Bergdoll clinical & 6.75 \\
\hline 2 & & FRI A - 100 & Bergdoll clinical & 6.66 \\
\hline 3 & & FRI 137 & Bergdoll clinical & 6.55 \\
\hline 4 & & CB 51 & Dairy; product & 5.01 \\
\hline 5 & & S 133 & Human; clinical & 4.67 \\
\hline 6 & & S 139 & Bovine; mastitis & 4.66 \\
\hline 7 & & CB 28 & Dairy; environmental & 3.85 \\
\hline 8 & & SS 92 & Dairy; product & 3.84 \\
\hline 9 & & FRI S6 & Bergdoll clinical & 3.80 \\
\hline 10 & & S 130 & Human; clinical & 3.79 \\
\hline 11 & & Clboye 1 & Human; clinical & 3.77 \\
\hline 12 & & S 35 & Dairy; product & 3.74 \\
\hline 13 & & S 118 & Human; clinical & 3.61 \\
\hline 14 & & S 107 & Bovine; mastitis & 3.40 \\
\hline 15 & & S 27 & Dairy; product & 2.50 \\
\hline 16 & & S 36 & Dairy; product & 2.39 \\
\hline 17 & & ATCC $^{2} 25923$ & Human; clinical (USA) & 2.37 \\
\hline 18 & & S 138 & Bovine; mastitis & 2.36 \\
\hline 19 & & $\mathrm{NZRM}^{3} 103$ & Human; clinical (food poisoning) & 2.06 \\
\hline 20 & & S 38 & Dairy: product & 1.95 \\
\hline 21 & & TRD & Dairy; environmental & 1.82 \\
\hline 22 & & S 120 & Human; clinical & 1.80 \\
\hline 23 & & NZRM 2016 & Bovine; clinical (UK) & 1.80 \\
\hline 24 & & S 52 & Dairy; product & 1.76 \\
\hline 25 & & S 99 & Dairy; product & 1.73 \\
\hline 26 & & S 140 & Bovine; mastitis & 1.70 \\
\hline 27 & & S 51 & Dairy; product & 1.63 \\
\hline 28 & & S 34 & Dairy; product & 1.61 \\
\hline 29 & & S 83 & Dairy; product & 1.59 \\
\hline 30 & & CB 21 & Dairy; environmental & 1.56 \\
\hline 31 & & FRI 472 & Bergdoll clinical & 1.44 \\
\hline 32 & & S 84 & Dairy; product & 1.08 \\
\hline 33 & & S 28 & Dairy; product & 1.01 \\
\hline 34 & & S 39 & Dairy; product & 0.99 \\
\hline 35 & & ER $1-34$ & Dairy; product & 0.87 \\
\hline 36 & & $\mathrm{~S} 12$ & Dairy; product & 0.64 \\
\hline 37 & & S 76 & Bovine; mastitis & 0.53 \\
\hline 38 & & S 100 & Dairy; product & 0.36 \\
\hline \multicolumn{5}{|c|}{ Yersinia enterocolitica } \\
\hline 1 & aleted & $\mathrm{AA} 71^{4}$ & Human; clinical & 4.02 \\
\hline 2 & & RWM $5^{5}$ & Dairy; product & 3.71 \\
\hline 3 & & $\mathrm{Aa} 65^{4}$ & Human; clinical & 3.70 \\
\hline 4 & & $\mathrm{~A} 85^{4}$ & Goat; clinical & 3.69 \\
\hline 5 & & $\mathrm{AA} 72^{4}$ & Human; clinical & 3.67 \\
\hline 6 & & PM33984 & Sheep; clinical & 3.62 \\
\hline 7 & & $\mathrm{AA} 67^{4}$ & Human; clinical & 3.59 \\
\hline 8 & & RWM 51 & Dairy; product & 3.58 \\
\hline 9 & & RWM 71 & Dairy; product & 3.53 \\
\hline 10 & & QJA0095 $5^{4}$ & Human; clinical & 3.52 \\
\hline 11 & & RWM 55 & Dairy; product & 3.49 \\
\hline 12 & & $020077 / 1^{4}$ & Cow; clinical & 3.46 \\
\hline 13 & & $\mathrm{ATCC}^{2} 9610$ & Human; clinical (USA). Type strain & 3.43 \\
\hline 14 & & RWM 69 & Dairy; product & 3.40 \\
\hline 15 & & RWM 9 & Dairy; product & 3.32 \\
\hline 16 & & RWM 7 & Dairy; product & 3.32 \\
\hline 17 & & RWM 53 & Dairy; product & 3.29 \\
\hline 18 & & A129 & Goat; clinical & 3.24 \\
\hline 19 & & $\mathrm{NZRM}^{3} 2603$ & Human; clinical (USA). Type strain & 3.13 \\
\hline 20 & & RWM 70 & Dairy; product & 3.10 \\
\hline 21 & & RWM 73 & Dairy; product & 3.05 \\
\hline 22 & & RWM 72 & Dairy; product & 3.04 \\
\hline 23 & & RWM 8 & Dairy; product & 3.04 \\
\hline 24 & & RWM 67 & Dairy; product & 3.02 \\
\hline
\end{tabular}


Table 1 (Continued). Strain number, name, origin, and submerged coil unit heat sensitivity of pathogen isolates

\begin{tabular}{|c|c|c|c|c|}
\hline $\begin{array}{l}\text { Species/ } \\
\text { strain no. }\end{array}$ & $\begin{array}{l}\text { Salmonella } \\
\text { serotypes }\end{array}$ & Strain $^{1}$ & Origin & $\begin{array}{l}\log \\
\text { reduction }\end{array}$ \\
\hline 25 & & RWM 65 & Dairy; product & 2.92 \\
\hline 26 & & NZRM 3595 & Human; clinical & 2.91 \\
\hline 27 & & RWM 64 & Dairy; product & 2.89 \\
\hline 28 & & NZRM 3596 & Human; clinical & 2.84 \\
\hline 29 & & RWM 12 & Dairy; product & 2.31 \\
\hline 30 & & RWM 11 & Dairy; product & 0.68 \\
\hline \multicolumn{5}{|c|}{ Escherichia coli } \\
\hline 1 & & E 4 & Dairy; product & 4.96 \\
\hline 2 & & E 7 & Dairy; product & 4.84 \\
\hline 3 & & E 6 & Dairy; product & 4.36 \\
\hline 4 & & E 5 & Dairy; product & 3.88 \\
\hline 5 & & E 8 & Dairy; product & 3.30 \\
\hline 6 & & E 18 & Dairy; product & 3.23 \\
\hline 7 & & E 42 & Bovine; clinical & 3.08 \\
\hline 8 & & $\mathrm{NZRM}^{3} 1661$ (EPEC) & Human; clinical & 3.08 \\
\hline 9 & & E 14 & Dairy; product & 2.93 \\
\hline 10 & & E15 & Dairy; product & 2.87 \\
\hline 11 & & E 16 & Dairy; product & 2.77 \\
\hline 12 & & E 20 & Dairy; product & 2.74 \\
\hline 13 & & E 23 & Dairy; environmental & 2.33 \\
\hline 14 & & NZRM 3020 (ETEC) & Animal; clinical & 2.14 \\
\hline 15 & & E 13 & Dairy; product & 1.91 \\
\hline 16 & & $\begin{array}{l}\text { NZRM } 3614 \\
\text { (VTEC, attenuated) }\end{array}$ & Not given & 1.39 \\
\hline 17 & & E 21 & Dairy; product & 1.10 \\
\hline 18 & & E 19 & Dairy; product & 1.03 \\
\hline 19 & & E 17 & Dairy; product & 0.99 \\
\hline 20 & & E 31 & Bovine; mastitis & 0.97 \\
\hline 21 & & E 54 & Bovine; mastitis & 0.96 \\
\hline 22 & & E 41 & Bovine; clinical & 0.84 \\
\hline 23 & & E 27 & Bovine; mastitis & 0.75 \\
\hline 24 & & NZRM 4164 (VTEC) & Human; clinical & 0.55 \\
\hline 25 & & O157:H16 Attenuated & Lettuce & 0.44 \\
\hline 26 & & O157:H42 Attenuated & Meat & 0.34 \\
\hline 27 & & NZRM 4156 (VTEC) & Environmental & 0.27 \\
\hline 28 & & E 9 & Dairy; product & 0.15 \\
\hline 29 & & AE 28 & Dairy; product & 0.14 \\
\hline \multicolumn{5}{|c|}{ Cronobacter sakazakii } \\
\hline 1 & & $578349-7$ & Dairy; environmental & 5.86 \\
\hline 2 & & $576736-3$ & Dairy; environmental & 5.60 \\
\hline 3 & & $\mathrm{NZRM}^{3} 868^{6}$ & Type strain & 5.04 \\
\hline 4 & & $\mathrm{FSL}^{7} \mathrm{~F} 6-049$ & Human; clinical & 4.63 \\
\hline 5 & & $3465-6$ & Dairy; environmental & 4.44 \\
\hline 6 & & FSL F6-035 & Human; clinical & 4.28 \\
\hline 7 & & $3465-4$ & Dairy; environmental & 4.22 \\
\hline 8 & & $7648-4$ & Dairy; environmental & 4.18 \\
\hline 9 & & FSL F6-030 & Food & 3.79 \\
\hline 10 & & FSL F6-029 & Human; clinical & 3.78 \\
\hline 11 & & FSL F6-034 & Human; clinical & 3.61 \\
\hline 12 & & FSL F6-033 & Food & 3.56 \\
\hline 13 & & FSL F6-032 & Food & 3.38 \\
\hline 14 & & FSL F6-043 & Human; clinical & 3.36 \\
\hline 15 & & NZRM $2375^{8}$ & Type strain & 3.18 \\
\hline 16 & & NZRM 4297 & Human clinical (infant) & 3.07 \\
\hline 17 & & NZRM 50 & Dairy; product (UK) & 3.04 \\
\hline 18 & & FSL F6-047 & Food & 3.03 \\
\hline 19 & & ATCC $^{2} 29544$ & Human; clinical. Type strain & 2.96 \\
\hline 20 & & FSL F6-044 & Food $^{7}$ & 2.85 \\
\hline 21 & & FSL F6-046 & Food $^{7}$ & 2.75 \\
\hline 22 & & FSL F6-045 & Food $^{7}$ & 2.72 \\
\hline 23 & & EWFAKRC11NNV1493 & FDA $^{9} 712$ & 2.13 \\
\hline
\end{tabular}


Table 1 (Continued). Strain number, name, origin, and submerged coil unit heat sensitivity of pathogen isolates

\begin{tabular}{|c|c|c|c|c|}
\hline $\begin{array}{l}\text { Species/ } \\
\text { strain no. }\end{array}$ & $\begin{array}{l}\text { Salmonella } \\
\text { serotypes }\end{array}$ & Strain $^{1}$ & Origin & $\begin{array}{l}\mathrm{Log} \\
\text { reduction }\end{array}$ \\
\hline 24 & & FSL F6-023 & Human; clinical & 1.96 \\
\hline 25 & & FSL F6-024 & Food & 1.84 \\
\hline 26 & & LCDC 648 & FDA 709 & 1.12 \\
\hline 27 & & SK90 & FDA 708 & 1.12 \\
\hline 28 & & 607 & Human; clinical (FDA 705) & 0.93 \\
\hline 29 & & $4.01 \mathrm{C}$ & Dairy; product (FDA 713) & 0.85 \\
\hline 30 & & FSL F6-028 & Human; clinical & 0.56 \\
\hline \multicolumn{5}{|c|}{ Listeria monocytogenes } \\
\hline 1 & & NZRM $^{3} 4244$ & Human; clinical & 3.53 \\
\hline 2 & & NZRM 4245 & Human; clinical & 3.30 \\
\hline 3 & & NZRM 4240 & Human; clinical & 3.22 \\
\hline 4 & & ATCC $^{2} 19111$ & Poultry (UK) & 3.17 \\
\hline 5 & & NZRM 4238 & Human; clinical & 3.12 \\
\hline 6 & & $\mathrm{NCTC}^{10} 11288^{11}$ & Bovine; clinical & 3.12 \\
\hline 7 & & NZRM 4239 & Human; clinical & 3.11 \\
\hline 8 & & LM 227 & Dairy; product & 3.11 \\
\hline 9 & & NZRM 4233 & Human; clinical & 3.10 \\
\hline 10 & & NZRM 4243 & Human; clinical & 3.07 \\
\hline 11 & & NZRM 4231 & Human; clinical & 3.07 \\
\hline 12 & & Lichfield L3 & Dairy; environmental & 3.06 \\
\hline 13 & & NZRM 4234 & Human; clinical & 3.04 \\
\hline 14 & & NZRM 4230 & Human; clinical & 3.04 \\
\hline 15 & & Te Awamutu L3 & Dairy; environmental & 3.04 \\
\hline 16 & & NZRM 4246 & Human; clinical & 3.04 \\
\hline 17 & & NZRM 4232 & Human; clinical & 3.03 \\
\hline 18 & & NZRM 4235 & Human; clinical & 3.03 \\
\hline 19 & & LM 232 & Dairy; product & 2.99 \\
\hline 20 & & Maungaturoto L3 & Dairy; environmental & 2.99 \\
\hline 21 & & NZRM 4236 & Human; clinical & 2.94 \\
\hline 22 & & Edendale L3 & Dairy; environmental & 2.92 \\
\hline 23 & & Kauri L3 & Dairy; environmental & 2.92 \\
\hline 24 & & Tirau L3 & Dairy; environmental & 2.88 \\
\hline 25 & & LM 55787 & Dairy; product & 2.87 \\
\hline 26 & & Whareroa L3 & Dairy; environmental & 2.69 \\
\hline 27 & & NZRM 4241 & Human; clinical & 1.93 \\
\hline 28 & & NZRM 4237 & Human; clinical & 1.83 \\
\hline 29 & & NZRM 4242 & Human; clinical & 1.66 \\
\hline \multicolumn{5}{|l|}{ Salmonella } \\
\hline 1 & Hindmarsh & NZRM $^{3} 4204$ & Sheep & 3.42 \\
\hline 2 & Typhimurium $\varnothing$ type 101 & NZRM 4216 & Human & 3.32 \\
\hline 3 & Paratyphi b var. java & NZRM 4211 & Human & 3.25 \\
\hline 4 & Infantis & NZRM 4200 & Human & 3.24 \\
\hline 5 & Typhimurium $\varnothing$ type 74 & NZRM 4218 & Dog & 3.19 \\
\hline 6 & Typhimurium $\varnothing$ type 160 & NZRM 4214 & Feline & 3.17 \\
\hline 7 & II $42: \mathrm{g}, \mathrm{t}:-$ & NZRM 4209 & Skink & 3.14 \\
\hline 8 & Mbandaka & $658712-4$ & Food industry & 3.13 \\
\hline 9 & Montevideo & NZRM 4222 & Human & 3.12 \\
\hline 10 & Typhimurium $\varnothing$ type rdnc & NZRM 4219 & Human & 3.11 \\
\hline 11 & Uuganda & $629676-1$ & Dairy; environmental & 3.10 \\
\hline 12 & Typhimurium $\varnothing$ type $12 \mathrm{a}$ & $637012-16$ & Food industry & 3.10 \\
\hline 13 & Adelaide & $655580-1$ & Food industry & 3.09 \\
\hline 14 & Agona & NZRM 4210 & Human & 3.08 \\
\hline 15 & Typhimurium $\varnothing$ type $12 \mathrm{a}$ & NZRM 4215 & Human & 3.08 \\
\hline 16 & Typhimurium $\varnothing$ type 42 & $630046-1$ & Dairy; environmental & 3.08 \\
\hline 17 & Brandenburg & NZRM 4202 & Environmental & 3.05 \\
\hline 18 & Typhimurium $\varnothing$ type 8 & $654469-16$ & Food industry & 3.05 \\
\hline 19 & Paratyphi a & NZRM 4223 & Human & 3.03 \\
\hline 20 & Hadar & NZRM 4206 & Human & 3.03 \\
\hline 21 & Havana & NZRM 4205 & Poultry; environmental & 3.02 \\
\hline 22 & Thompson & NZRM 4207 & Eggshell & 3.02 \\
\hline 23 & Orion $15+$ & NZRM 4221 & Food & 3.02 \\
\hline 24 & Enteriditis & NZRM 4201 & Human & 3.01 \\
\hline
\end{tabular}


Table 1 (Continued). Strain number, name, origin, and submerged coil unit heat sensitivity of pathogen isolates

\begin{tabular}{|c|c|c|c|c|}
\hline $\begin{array}{l}\text { Species/ } \\
\text { strain no. }\end{array}$ & $\begin{array}{l}\text { Salmonella } \\
\text { serotypes }\end{array}$ & Strain $^{1}$ & Origin & $\begin{array}{l}\mathrm{Log} \\
\text { reduction }\end{array}$ \\
\hline 25 & Infantis & $653595-5$ & Food industry & 3.01 \\
\hline 26 & II $3,10:-: 1,5$ & $617986-4$ & Dairy; product (Australia) & 3.00 \\
\hline 27 & Uganda & NZRM 4208 & Human & 2.99 \\
\hline 28 & Menston & NZRM 4203 & Control strain & 2.98 \\
\hline 29 & Montevideo & NZRM 4199 & Human & 2.97 \\
\hline 30 & Typhimurium $\varnothing$ type 1 & NZRM 4220 & Human & 2.97 \\
\hline 31 & Mississippi & NZRM 4213 & Human & 2.87 \\
\hline 32 & Heidelburg & NZRM 4212 & Human & 2.87 \\
\hline
\end{tabular}

${ }^{1}$ Cultures are from the Fonterra Research Centre collection and isolated in New Zealand unless otherwise stated.

${ }^{2}$ American Type Culture Collection (Manassas, VA).

${ }^{3}$ New Zealand Reference Culture Collection, Medical Section, Environmental and Scientific Research.

${ }^{4}$ Massey University (New Zealand).

${ }^{5}$ Yersinia frederickensii.

${ }^{6}$ Citrobacter koseri.

${ }^{7}$ International Life Science Institute Collection, Cornell University (Ithaca, NY).

${ }^{8}$ Enterobacter cloacae.

${ }^{9}$ US FDA Collection.

${ }^{10}$ National Collection of Type Cultures.

${ }^{11}$ Listeria innocua.

Original cultures were obtained in freeze-dried form, as frozen isolates, or as live cultures on agar slopes. A single typical, well-isolated colony was selected from each culture and grown in trypticase soy broth (TSB). The purity and identity of these cultures were confirmed using appropriate biochemical and other tests. Sufficient ampoules of the selected cultures were prepared and frozen at $-84^{\circ} \mathrm{C}$ to enable a fresh ampoule to be used for each laboratory trial, for each pilot-plant-scale experiment, and for a final confirmation of taxonomic identity. Identification and species confirmation utilizing the GenBank database was carried out by internetbased 16S rRNA gene sequence comparison software with 10 strains from the same species (Pearson and Lipman, 1988).

\section{Growth Media and Conditions}

Inocula for laboratory screening of panels of strains were grown in TSB. Plate counts for the screening experiments were performed on TSB with $1.5 \%$ agar (both from Merck, Darmstadt, Germany). Growth and recovery media and conditions for cultures for the pilotplant-scale pasteurizer trials are given in Table 2 .

\section{Heating Medium}

Raw milk supplied by the Fonterra Co-operative Group Ltd. (New Zealand) was used. The milk was standardized to $4.26 \%$ fat and $3.4 \%$ protein, which are typical mid dairy season values for New Zealand milk. The TS contents of the milks were approximately $13 \%$

Table 2. Inocula for pilot-plant-scale pasteurizer, growth and recovery media, and anaerobic recovery conditions

\begin{tabular}{|c|c|c|c|}
\hline Organism & $\begin{array}{l}\text { Growth media } \\
\text { and conditions }{ }^{1,2}\end{array}$ & $\begin{array}{l}\text { Recovery } \\
\text { medium }\end{array}$ & $\begin{array}{l}\text { Anaerobic } \\
\text { incubation }\end{array}$ \\
\hline Staphylococcus aureus $\mathrm{S} 12$ & $\mathrm{BHIB}^{3} 20 \mathrm{~h}$ & $\mathrm{TSA}^{4}+$ pyruvate & No \\
\hline Yersinia enterocolitica NZRM $^{5} 3596$ & $\operatorname{TSB}^{6} 20 \mathrm{~h}$ & Columbia base & No \\
\hline Escherichia coli O157:H42 (attenuated) & TSB $12 \mathrm{~h}$ & Columbia base & No \\
\hline Cronobacter sakazakii $\mathrm{F} 6-028$ & TSB $12 \mathrm{~h}$ & Columbia base & Yes \\
\hline Listeria monocytogenes NZRM 4237 & BHIB + yeast extract $16 \mathrm{~h}$ & Columbia base & No \\
\hline Salmonella ser. Typhimurium NZRM 4220 & TSB $12 \mathrm{~h}$ & Columbia base & No \\
\hline
\end{tabular}

\footnotetext{
${ }^{1}$ All cultures were incubated at $30^{\circ} \mathrm{C}$.

${ }^{3}$ Brain-heart infusion broth.

${ }^{4}$ Trypticase soy agar.

${ }^{5}$ New Zealand Reference Culture Collection, Medical Section, Environmental and Scientific Research.

${ }^{6}$ Trypticase soy broth.
}

${ }^{2}$ When 2 pasteurizer runs were carried out on the same day, 2 separate ampoules were used to prepare fresh cultures for each of the 2 inocula. 


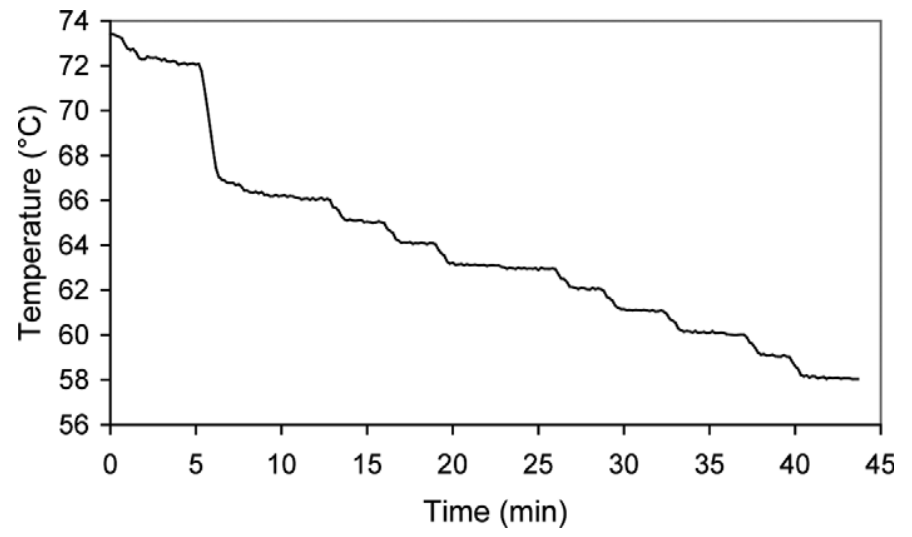

Figure 1. Temperature control during a continuous heat inactivation run of UHT whole milk inoculated with Salmonella ser. Typhimurium NZRM (New Zealand Reference Culture Collection) 4220. Samples for analysis were taken after equilibration for at least $45 \mathrm{~s}$ at each selected temperature.

(Auldist et al., 1998). Both the laboratory screening of cultures and the pilot-plant-scale pasteurizer runs were carried out in UHT, $141^{\circ} \mathrm{C}$ for $4 \mathrm{~s}$, standardized whole milk. For the laboratory screening of cultures, the milk was first homogenized before UHT treatment, after which $\sim 240 \mathrm{~mL}$ aliquots of $20-\mathrm{L}$ batches were aseptically dispensed into $250-\mathrm{mL}$ bottles. A new bottle was used for the submerged coil unit (SCU) runs on any 1 d. For the pilot-plant-scale runs, $3 \times 120$-L batches of the standardized UHT milk were prepared for triplicate runs. This milk was not homogenized.

The choice of UHT milk determined the subsequent protocol design. It provided a reproducible screening medium, eliminated the need for selective plating agar, and minimized the procedures needed to ensure the recovery of the maximum number of heat-stressed cells.

\section{Heating Strategy}

Growth models such as the US FDA Pathogen Modeling Program typically use a cocktail of strains to allow for inevitable variations in growth rates of different strains under a variety of substrates or conditions. With heat inactivation challenge trials, however, the most heat-resistant strain of a species is needed to give a worst-case scenario. A mixture of several different heat tolerances would distort the survival curves. Different strains are also likely to respond differently to the various recovery conditions, requiring compromise media suited to the recovery of more than one strain. Therefore, the single most heat-resistant strain of each species was chosen.

A single temperature point was used as the straightforward approach to finding the most heat resistant of the 30 strains of each pathogen species. Relative heat tolerance between strains at $60^{\circ} \mathrm{C}$ (or $62.5^{\circ} \mathrm{C}$ in the case of $L$. monocytogenes) was assumed to parallel relative tolerances at other temperatures, in particular $72^{\circ} \mathrm{C}$. That is, a similar $z$-value was assumed to apply between strains of the same species.

\section{Efficiency of Plating}

Heating pathogens in commercially sterile UHT milk meant that survivors did not require selective conditions for recovery and enumeration. Using the single most heat-resistant strain from each pathogen group allowed selection of the most appropriate recovery medium giving the highest efficiency of plating. Compromise media suited to more than one strain were not necessary.

\section{Safety Screening}

The safety of the laboratory SCU and the pilot-plantscale pasteurizer was evaluated by circulating a doubledrug-resistant Lactococcus lactis mutant through each piece of equipment. A combination of exposure plates, swabbing, and air sampling was used to detect aerosols. Neither piece of equipment showed evidence of leaks or aerosols. Pathogens that were known to be highly infective were screened in a PC2 laboratory.

\section{Laboratory Screening}

An SCU was chosen for the laboratory screening of strains of each pathogen for heat resistance (Cole and Jones, 1990). Two different units were used: an early model (Protrol Instruments, West Byfleet, Surrey, UK) and a more recent model (Sherwood Instruments, Lynfield, MA).

Typically, a frozen working stock was thawed, diluted to $\sim 10^{3} / \mathrm{mL}$ in TSB, and grown for $20 \mathrm{~h}$ at $30^{\circ} \mathrm{C}$. This culture was in turn diluted to $\sim 10^{3} / \mathrm{mL}$ in fresh TSB and incubated for $20 \mathrm{~h}$ at $30^{\circ} \mathrm{C}$ to provide the inoculum. Stationary phase cells of each strain within each species to be screened were inoculated at $1 \%$ for each strain into UHT milk to give $\sim 10^{7} / \mathrm{mL}$ for each SCU run. Preliminary screening established temperatures and times that gave no more than a $10^{7}$-fold reduction of a selection of strains of each species. Single strains were then heated at $62.5^{\circ} \mathrm{C}$ for $60 \mathrm{~s}$ for L. monocytogenes or at $60^{\circ} \mathrm{C}$ for $60 \mathrm{~s}$ for the other 5 pathogens, and the $\log _{10}$ reductions were determined from survivor counts. Varying degrees of cell adhesion to the surface of the exit port of this type of SCU were described (Keller et al., 2008). This led to non-log-linear growth rates with tailing. In the present study, only a single sample was taken in each run, and the SCU was sanitized after each sampling. 
Table 3. Mean log reduction of pathogenic and nonpathogenic Escherichia coli O157 strains from submerged coil unit screening experiments

\begin{tabular}{|c|c|c|c|c|}
\hline Strain & Serotype & $\begin{array}{l}\text { Pathogen } \\
\text { type }\end{array}$ & $\begin{array}{l}\text { Mean } \log _{10} \\
\text { reduction }\end{array}$ & SD \\
\hline NZRM $^{1} 4156$ & O157:H7 & EHEC $^{2}$ & 0.27 & 0.14 \\
\hline \multirow{2}{*}{ CPH 0512717} & O157:H42 & Attenuated & 0.34 & 0.07 \\
\hline & O157:H16 & Attenuated & 0.44 & 0.13 \\
\hline NZRM 4164 & O157:H7 & EHEC & 0.55 & 0.12 \\
\hline NZRM 3614 (NCTC $\left.{ }^{3} 12900\right)$ & $\mathrm{O} 157: \mathrm{H} 7$ & Attenuated & 1.39 & 0.01 \\
\hline NZRM 3020 & K 99 & ETEC $^{4}$ & 2.14 & 0.10 \\
\hline NZRM 1661 (NCTC 8621) & K 61 & EPEC $^{5}$ & 3.08 & 0.00 \\
\hline
\end{tabular}

${ }^{1}$ New Zealand Reference Culture Collection, Medical Section, Environmental and Scientific Research.

${ }^{2}$ Enterohemorrhagic E. coli.

${ }^{3}$ National Collection of Type Cultures.

${ }^{4}$ Enterotoxigenic E. coli.

${ }^{5}$ Enteropathogenic E. coli.

Duplicate runs were carried out on the same day. The strains showing the highest resistance were retested at least twice to select the most resistant from the panel of each species. The SCU was cleaned and sanitized after each sample was taken, with a $60-\mathrm{mL}$ rinse of $1.5 \%$ aqueous $\mathrm{NaOH}$, then a $60-\mathrm{mL}$ rinse of $1.5 \%$ aqueous $\mathrm{H}_{2} \mathrm{SO}_{4}$, and a $120-\mathrm{mL}$ rinse of sterile water. Sterility was checked by plating a sample of the final rinse water.

\section{Pilot-Plant-Scale Milk Pasteurizer}

The basic pilot-plant-scale pasteurizer used in this study and its operation have been described previously (Pearce et al., 2001). It was relocated to a PC2 laboratory installed adjacent, but external, to the Fonterra Research Centre dairy processing facility. Additional safety modifications were introduced for handling pathogens. A stirred, sealable 140-L tank for holding the UHT milk substrate was installed. After heat treatment and sampling, the milk was heat treated by direct steam injection to $85^{\circ} \mathrm{C}$ to remove pathogens and was then diluted and piped to waste.

Essential features of the pasteurizer were maximum throughput of $120 \mathrm{~L} / \mathrm{h}$; turbulent flow (Reynold's Number >11,000; Kessler, 1981a), verified by residence time distribution; and separate heat exchangers for heating and cooling the milk to remove the possibility of crosscontamination between the untreated and treated milk flow. Temperature probes were recalibrated before the plant was used and were rechecked subsequent to the pathogen runs.

\section{Pilot-Scale Plant Operation in Heat Inactivation Trials}

Three 120-L batches of UHT milk for the triplicate heat inactivation runs were aseptically poured into individual fermentation vessels, chilled to $4^{\circ} \mathrm{C}$, and held for up to $48 \mathrm{~h}$. The first 2 heat inactivation runs were carried out on the first day, with the third run on the following day. The UHT milk was warmed to $7^{\circ} \mathrm{C}$ to reduce the effect of cold shock and then pumped into the balance tank. The incubation time to reach stationary phase at $30^{\circ} \mathrm{C}$ in the appropriate broth was initially determined for each organism (Table 2). Growth was measured by the change in impedance following incubation in a Bactrac 4000 (Sylab, Vienna, Austria). Concentration of these inocula to give higher starting populations was rejected as being unsafe. Furthermore, a 10-fold increase in numbers would, for example, barely give another point on the heat inactivation curve.

A 1-L batch of the pathogen for each heat inactivation run was grown to stationary phase $\left(\sim 10^{9} / \mathrm{mL}\right)$ according to the same protocol and inoculum proportions as determined in the earlier laboratory trials. To minimize the effect of any cold shock, and to maximize recovery of the heat treatment survivors, the inocula were not chilled and were used as soon as harvested. The culture was transferred to a sterilized stainless steel inoculation vessel and placed in the inoculation port of the balance tank. The inoculum was then gravity fed into the balance tank and stirred for 20 min to mix to homogeneity.

The pasteurizer was started up on water and equilibrated to the initial temperature point of $72^{\circ} \mathrm{C}$ on milk. It was then shifted down at intervals of $1^{\circ} \mathrm{C}$ by adjusting the steam valve setting through the temperature region in which the pathogens were inactivated. The pasteurizer was equilibrated to each set temperature. A zero-time unheated control sample was taken via a septum using a BD Vacutainer (Preanalytical Solutions, Franklin Lakes, NJ). A similar mid-run control sample was also taken to confirm adequate mixing. The temperatures of the milk exiting the holding tube were recorded (Figure 1). The samples were held on ice and were processed within an hour. 


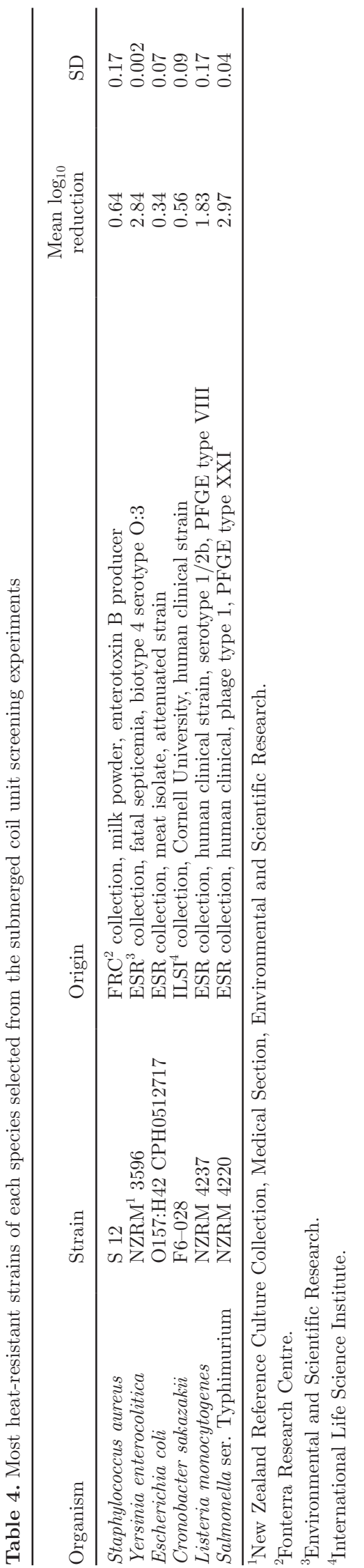

\section{Pilot-Plant-Scale Pasteurizer Cleaning}

The pasteurizer equipment was cleaned in place before and after each experiment. The plant was rinsed with cold water, circulated with $1 \%$ (wt/vol) aqueous $\mathrm{NaOH}\left(75^{\circ} \mathrm{C}, 30 \mathrm{~min}\right)$, and rinsed with warm soft water $\left(75^{\circ} \mathrm{C}, 15 \mathrm{~min}\right)$. Nitric acid solution $\left(0.7 \% \mathrm{wt} / \mathrm{vol}, 70^{\circ} \mathrm{C}\right)$ was then circulated for 15 min at the maximum pump rate of $200 \mathrm{~kg} / \mathrm{h}$. The pasteurizer was then sterilized by recirculating $85^{\circ} \mathrm{C}$ hot water for 5 min before each trial.

\section{Data Analysis}

The thermal inactivation data were analyzed using the first-order kinetic model, where $t$ is time ; $N(t)$ is the number of viable organisms at a time $t ; N(0)$ is the number of viable organisms at $t=0$; and the inactivation constant $k$ is usually calculated by ordinary least squares from the slope of the $\ln \left(N / N_{0}\right)$ versus time plot (Kessler, 1981b).

$$
\frac{N(t)}{N_{0}}=e^{-k t} .
$$

However, least squares cannot be used when only 2 time points (initial and final) are available, as with the pilot-plant-scale pasteurizer. By rearranging equation [1]

$$
k=-\log \left(N / N_{0}\right) \frac{2.3026}{t},
$$

where $t=15 \mathrm{~s}$, the decimal reduction time $D$ is found directly from $k$ as

$$
D=\ln (10) / k=2.3026 / k \text {. }
$$

The relationship between $D$ and $\log _{10}$ kill is derived directly from equations [1] and [3]:

$$
\log _{10} \text { kill }=t / D \text {. }
$$

Early work by Bigelow and Esty (1920) and Bigelow (1921) showed a linear relationship between the logarithm of the decimal reduction time $(\boldsymbol{D})$ and the temperature. This model has been used for many years in the canning industry, whereby a certain temperature change, defined as the $z$-value, will alter the decimal reduction time by a factor of 10 . This $z$-value is constant for all temperatures and is usually calculated from the results obtained from inactivation using a range of time and temperature combinations. This above simple model works well in situations where the temperature 

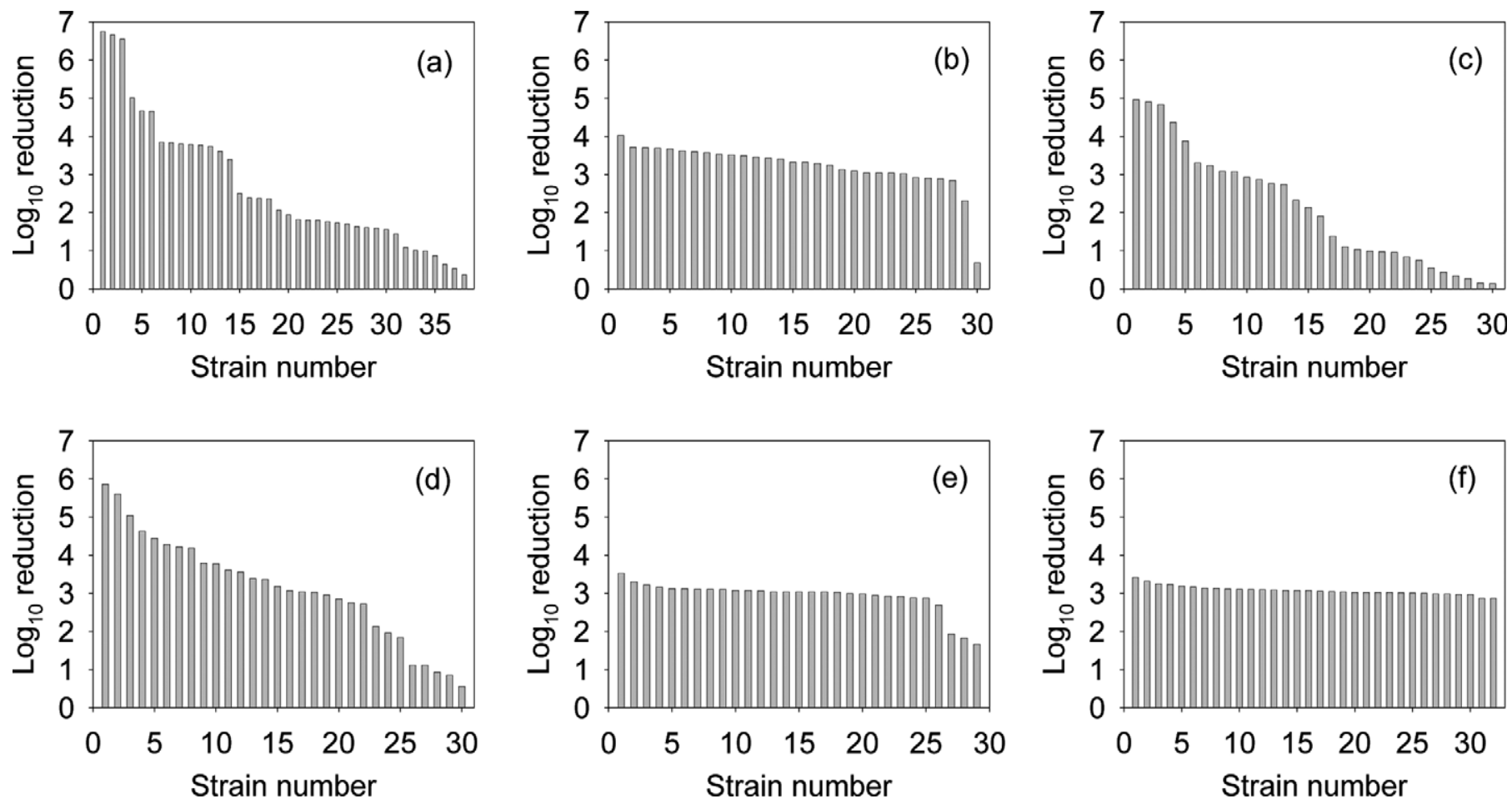

Figure 2. Mean $\log _{10}$ reduction of each of the approximately 30 strains of each pathogen group in submerged coil unit screening trials for the most heat-resistant isolate of each species. (a) Staphylococcus aureus, $60^{\circ} \mathrm{C}$ for $60 \mathrm{~s}, 38$ strains; (b) Yersinia enterocolitica, $60^{\circ} \mathrm{C}$ for $60 \mathrm{~s}, 30$ strains; (c) Escherichia coli, $60^{\circ} \mathrm{C}$ for $60 \mathrm{~s}, 30$ strains; (d) Cronobacter sakazakii, $60^{\circ} \mathrm{C}$ for $60 \mathrm{~s}, 30$ strains; (e) Listeria monocytogenes, $62.5^{\circ} \mathrm{C}$ for 60 s, 29 strains; (f) Salmonella serotypes, $60^{\circ} \mathrm{C}$ for $60 \mathrm{~s}, 32$ strains.

increase and decrease times are very short relative to the hold time. When the increase and decrease times are appreciable, for example, as in our pilot-plant-scale pasteurizer or in commercial practice, then a more rigorous model should be employed.

The differential equation

$$
\mathrm{d} N=-k(t, T) N(t) \mathrm{d} t
$$

has the solution

$$
\begin{gathered}
\frac{\mathrm{d} N}{N(t)}=-k(t, T) d t \\
\int \frac{\mathrm{d} N}{N(t)}=-\int k(t, T) \mathrm{d} t+\ln C \\
\operatorname{lm}|N(t)|=-\int k(t, T) \mathrm{d} t+\ln C \\
N(t)=c e^{-\int k(t, T) \mathrm{d} t} .
\end{gathered}
$$

As $k(t, T)$ is a continuous function, by the mean value theorem there exists $\bar{k}$ such that

$$
\bar{k}\left(t_{f i n}-t_{0}\right)=\int_{t_{0}}^{t_{f i n}} k(t, T) \mathrm{d} t
$$

and by substitution we find that

$$
\bar{k}=-\log \left(N / N_{0}\right) \frac{2.3026}{t},
$$

where $t=t_{f i n}-t_{0}$ is the time interval that a typical milk particle is within the pasteurizer.

This $\bar{k}$ as defined in equation [11] is the effective inactivation constant for the particular heat treatment applied.

Similarly, we can define

$$
\bar{D}=\ln (10) / \bar{k}=2.3026 / \bar{k},
$$

as the effective decimal reduction time of the heat treatment.

Thus, $\bar{D}$ and $\bar{k}$ can be used to compare and contrast different heat treatment regimens. In a $30-\mathrm{s}$ rise, 15 -s hold, and 15-s drop time regimen, the total time is 45 s. Hence, $\bar{D}$ values are 4 times as high as $D$ values based only on a 15 -s holding time. 
Table 5. Efficiency of plating of pathogens ${ }^{1}$ on various plating media after heat inactivation (counts expressed as $\log _{10} / \mathrm{mL}$ )

\begin{tabular}{|c|c|c|c|c|c|c|c|c|c|c|c|c|c|c|c|c|c|c|}
\hline \multirow[b]{2}{*}{$\begin{array}{l}\text { Plating } \\
\text { medium }\end{array}$} & \multicolumn{3}{|c|}{$\begin{array}{l}\text { Staph. aureus } \\
\text { (S 12) }\end{array}$} & \multicolumn{3}{|c|}{$\begin{array}{l}\text { Y. enterocolitica } \\
\left(\mathrm{NZRM}^{2} 3596\right)\end{array}$} & \multicolumn{3}{|c|}{$\begin{array}{l}\text { E. coli O157:H42 } \\
\text { (attenuated) }\end{array}$} & \multicolumn{3}{|c|}{$\begin{array}{l}\text { C. sakazakii } \\
\text { (F6-028) }\end{array}$} & \multicolumn{3}{|c|}{$\begin{array}{l}\text { L. monocytogenes } \\
\text { (NZRM 4237) }\end{array}$} & \multicolumn{3}{|c|}{$\begin{array}{l}\text { Salmonella ser. } \\
\text { Typhimurium } \\
\text { (NZRM 4220) }\end{array}$} \\
\hline & Con & $\begin{array}{l}55^{\circ} \mathrm{C} \\
30 \mathrm{~s}\end{array}$ & $\begin{array}{l}60^{\circ} \mathrm{C} \\
60 \mathrm{~s}\end{array}$ & Con & $\begin{array}{l}55^{\circ} \mathrm{C} \\
30 \mathrm{~s}\end{array}$ & $\begin{array}{l}60^{\circ} \mathrm{C} \\
60 \mathrm{~s}\end{array}$ & Con & $\begin{array}{l}60^{\circ} \mathrm{C} \\
30 \mathrm{~s}\end{array}$ & $\begin{array}{c}61.5^{\circ} \mathrm{C} \\
60 \mathrm{~s}\end{array}$ & Con & $\begin{array}{l}55^{\circ} \mathrm{C} \\
30 \mathrm{~s}\end{array}$ & $\begin{array}{l}60^{\circ} \mathrm{C} \\
60 \mathrm{~s}\end{array}$ & Con & $\begin{array}{l}57^{\circ} \mathrm{C} \\
30 \mathrm{~s}\end{array}$ & $\begin{array}{c}62.5^{\circ} \mathrm{C} \\
60 \mathrm{~s}\end{array}$ & Con & $\begin{array}{l}55^{\circ} \mathrm{C} \\
30 \mathrm{~s}\end{array}$ & $\begin{array}{l}60^{\circ} \mathrm{C} \\
60 \mathrm{~s}\end{array}$ \\
\hline Trypticase soy agar (TSA) ${ }^{3}$ & 6.83 & 6.75 & 4.80 & 6.79 & 6.74 & 3.81 & 6.87 & 6.74 & 6.34 & 6.86 & 7.04 & 6.18 & 7.11 & 7.11 & 6.25 & 7.01 & 6.90 & 2.78 \\
\hline $\mathrm{TSA}+0.6 \%$ yeast extract ${ }^{4}$ & 6.48 & 6.78 & 4.59 & 6.80 & 6.65 & 3.79 & 6.83 & 6.76 & 6.34 & 6.87 & 7.08 & 6.26 & 7.14 & 7.14 & 6.29 & 6.93 & 6.89 & 2.78 \\
\hline Columbia base agar $(\mathrm{CBA})^{4}$ & 6.76 & 6.77 & 5.51 & 6.78 & 6.63 & 3.83 & 6.99 & 6.83 & 6.65 & 6.92 & 7.08 & 6.41 & 7.13 & 7.17 & 6.81 & 6.93 & 6.90 & 3.15 \\
\hline TSA + pyruvate & 6.83 & 6.81 & 5.45 & & & & & & & & & & & & & & & \\
\hline TSA + egg yolk ${ }^{4}$ & 6.74 & 6.74 & 4.89 & & & & & & & & & & & & & & & \\
\hline TSA + egg yolk + pyruvate & 6.79 & 6.76 & 5.36 & & & & & & & & & & & & & & & \\
\hline $\mathrm{CBA}+$ pyruvate & 6.88 & 6.81 & 5.43 & & & & & & & & & & & & & & & \\
\hline Baird-Parker (BP) agar base ${ }^{4}$ & 6.78 & 6.70 & 5.56 & & & & & & & & & & & & & & & \\
\hline BP agar base + egg yolk & 6.74 & 6.71 & 5.43 & & & & & & & & & & & & & & & \\
\hline BP agar base + egg yolk + tellurite ${ }^{4}$ & 6.81 & 6.76 & 5.26 & & & & & & & & & & & & & & & \\
\hline Brain-heart infusion agar (BHIA) ${ }^{3}$ & & & & 6.78 & 6.69 & 3.87 & 6.88 & 6.77 & 6.40 & 6.93 & 7.04 & 6.32 & & & & 6.91 & 6.89 & 2.85 \\
\hline BHIA + $0.6 \%$ yeast extract & & & & 6.77 & 6.70 & 3.67 & 6.83 & 6.79 & 6.46 & 6.88 & 7.04 & 6.26 & & & & 6.93 & 6.85 & 2.95 \\
\hline Nutrient agar $(\mathrm{NA})^{3}$ & & & & 6.84 & 6.62 & 3.60 & 6.94 & 6.34 & 6.00 & 6.83 & 7.08 & 6.49 & & & & & & \\
\hline $\mathrm{NA}+0.6 \%$ yeast extract & & & & 6.89 & 6.18 & 3.04 & 6.85 & 6.57 & 6.11 & 6.89 & 7.08 & 5.65 & & & & & & \\
\hline Milk plate count agar ${ }^{4}$ & & & & 6.79 & 6.08 & 3.11 & 6.91 & 6.45 & 6.41 & 6.83 & 7.00 & 5.76 & 7.14 & 7.18 & 6.20 & 6.88 & 6.85 & 2.70 \\
\hline Selective $\operatorname{agars}^{5}$ & 6.81 & 6.76 & 5.26 & 4.60 & 4.75 & 2.00 & 6.90 & 6.26 & 6.04 & 6.57 & 6.53 & 4.54 & 7.16 & 7.11 & 5.45 & 6.30 & 5.89 & 2.00 \\
\hline
\end{tabular}

${ }^{1}$ See Table 4 for strain descriptions.

${ }^{2}$ New Zealand Reference Culture Collection, Medical Section, Environmental and Scientific Research.

${ }^{3}$ Trypticase soy agar, brain-heart infusion agar, and nutrient agar are produced by Merck (Darmstadt, Germany).

${ }^{4}$ Yeast extract, Columbia base agar, egg yolk supplement, potassium tellurite supplement, Baird-Parker agar base, milk plate count agar, cefsulodin-Irgasan-novobiocin (CIN) agar, tryptone bile X-glucuronide (TBX) agar, and Druggan-Forsythe-Iversen (DFI) agar are products of Oxoid Ltd. (Basingstoke, UK).

${ }^{5}$ Selective agars used were Baird-Parker agar for Staph. aureus; CIN agar for Y. enterocolitica; TBX agar for E. coli: DFI agar for C. sakazakii; polymyxin-acriflavine-lithium chlorideceftazidime-esculin-mannitol (PALCAM) agar for L. monocytogenes, and Hektoen agar for Salmonella ser. Typhimurium. PALCAM agar and Hektoen agar are products of Difco Laboratories (Becton Dickinson Co., Sparks, MD). 

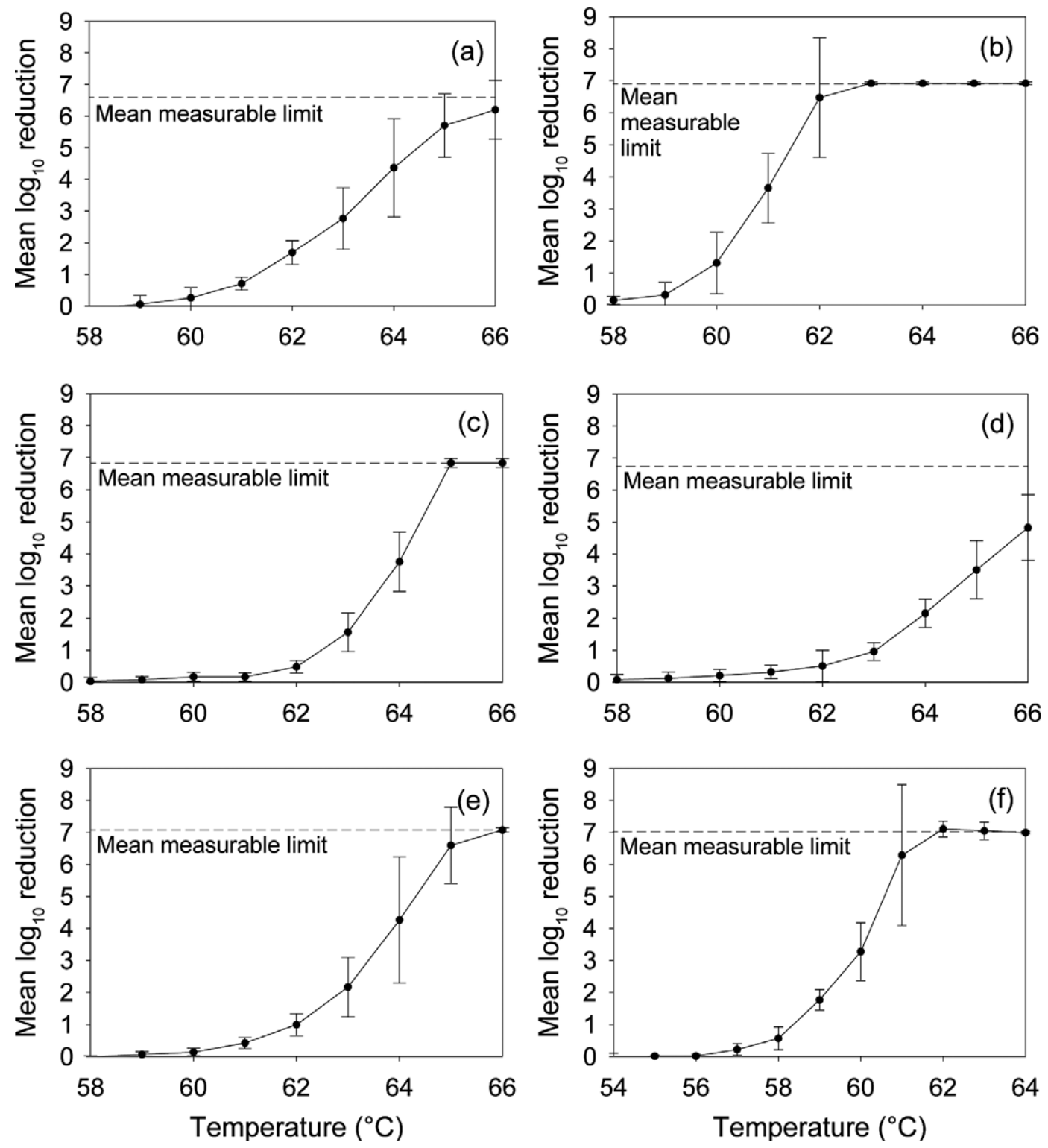

Figure 3. Mean $\log _{10}$ reduction of the most heat-resistant strains of the 6 milk borne pathogens at different temperatures in the pilot-plantscale pasteurizer. Bars are 95\% confidence intervals. (a) Staphylococcus aureus S 12; (b) Yersinia enterocolitica NZRM (New Zealand Reference Culture Collection) 3596; (c) Escherichia coli O157:H42 attenuated; (d) Cronobacter sakazakii F6-028; (e) Listeria monocytogenes NZRM 4237;

(f) Salmonella ser. Typhimurium NZRM 4220.

An Arrhenius relationship between temperature $(\boldsymbol{T})$ and $\bar{k}$ is assumed [13]:

$$
\bar{k}(T)=e^{\frac{-E_{a}}{R T}}
$$

Under this model, the equivalent time-temperature combinations lie in straight lines when $\log _{10} t$ is plotted against temperature for a small temperature range. These straight lines have a slope of $1 / z$. The slope of $\log _{10} \bar{k}$ versus $T$ has been shown to be approximately $1 / z$ over a narrow range; for example, from 60 to $80^{\circ} \mathrm{C}$
(Kessler, 1981b). The form of equation [3] shows that the relationship between $\log _{10} \bar{D}$ and $T$ will also be linear. Hence, least squares can be used to obtain an estimate of $z$ from the slope of the $\log _{10} \bar{D}$ versus $T$ graph. Least squares can simultaneously provide $95 \%$ confidence intervals for predicted values. These can then be used, with equation [4], to give $95 \%$ confidence intervals for $\log _{10}$ kill.

\section{RESULTS AND DISCUSSION}

The development of the heat inactivation protocol used in this study presented several challenges that 
PEARCE ET AL.

Table 6. $\bar{D}$-values (s) for the most heat-resistant pathogens of each species (average over 3 runs, with SD of 3 runs in parentheses) ${ }^{1}$

\begin{tabular}{|c|c|c|c|c|c|c|c|c|c|}
\hline \multirow[b]{2}{*}{ Strain } & \multicolumn{9}{|c|}{ Temperature $\left({ }^{\circ} \mathrm{C}\right)$} \\
\hline & 57 & 58 & 59 & 60 & 61 & 62 & 63 & 64 & 65 \\
\hline Staphylococcus aureus S 12 & & & & $\begin{array}{c}312 \\
(226)\end{array}$ & $\begin{array}{c}86 \\
(16)\end{array}$ & $\begin{array}{l}36 \\
(3)\end{array}$ & $\begin{array}{l}22 \\
(3)\end{array}$ & $\begin{array}{l}14 \\
(2)\end{array}$ & \\
\hline Yersinia enterocolitica $\mathrm{NZRM}^{2} 3596$ & & & $\begin{array}{c}247 \\
(168)\end{array}$ & $\begin{array}{c}48 \\
(13)\end{array}$ & $\begin{array}{l}17 \\
(2)\end{array}$ & & & & \\
\hline Escherichia coli O157:H42 CPH0512717 & & & & & $\begin{array}{c}435 \\
(157)\end{array}$ & $\begin{array}{c}132 \\
(37)\end{array}$ & $\begin{array}{l}39 \\
(7)\end{array}$ & $\begin{array}{l}16 \\
(2)\end{array}$ & \\
\hline Cronobacter sakazakii $\mathrm{F} 6-028$ & & & & $\begin{array}{c}316 \\
(123)\end{array}$ & $\begin{array}{l}195 \\
(49)\end{array}$ & $\begin{array}{l}134 \\
(64)\end{array}$ & $\begin{array}{l}63 \\
(8)\end{array}$ & $\begin{array}{l}28 \\
(2)\end{array}$ & $\begin{array}{l}17 \\
(2)\end{array}$ \\
\hline Listeria monocytogenes NZRM 4237 & & & & & $\begin{array}{l}146 \\
(34)\end{array}$ & $\begin{array}{c}61 \\
(8)\end{array}$ & $\begin{array}{l}28 \\
(5)\end{array}$ & $\begin{array}{l}14 \\
(3)\end{array}$ & \\
\hline Salmonella ser. Typhimurium NZRM 4220 & $\begin{array}{c}292 \\
(83)\end{array}$ & $\begin{array}{l}111 \\
(31)\end{array}$ & $\begin{array}{l}34 \\
(2)\end{array}$ & $\begin{array}{l}18 \\
(2)\end{array}$ & & & & & \\
\hline
\end{tabular}

${ }^{1} \bar{D}$ is the effective decimal reduction time for the entire heat treatment.

${ }^{2}$ New Zealand Reference Culture Collection, Medical Section, Environmental and Scientific Research.

had to be addressed if the results were to provide the kinetic data, which would support risk assessment of the significant pathogens in milk. These challenges can be summarized as follows.

\section{Choice of Milk for the Heat Inactivation Medium}

The heat inactivation of Staph. aureus NZRM 2016 was examined in raw whole milk and in the same milk after UHT treatment, with and without homogenization. Triplicate runs at each treatment showed no significant difference between the milk types $(P>0.05)$. The commercially sterile homogenized UHT milk could be held at $4^{\circ} \mathrm{C}$ for more than a month without separation of a cream layer, or any other detectable effect on its properties as a heating medium.

Changes in milk fat and protein contents are major elements in the seasonal compositional variation of milk (Auldist et al., 1998). These 2 variables have been reported to influence heat inactivation in other systems (Ma et al., 2007; Keller et al., 2008). By standardizing the milk substrate to $4.26 \%$ fat and $3.4 \%$ protein, the effect of this potential influence was effectively eliminated.

\section{Choice of Heating Method}

The SCU procedure gave reproducible results (Tables 3 and 4). The most resistant strains in our panel of C. sakazakii also corresponded to the highly resistant group described by others (Edelson-Mammel and $\mathrm{Bu}$ chanan, 2004). The single-point rapid screening method proved to be satisfactory and gave good reproducibility on repeated trials (Tables 3 and 4 ).

A pathogenic strain of $E$. coli $\mathrm{O} 157$ was among the most resistant of the E. coli panel. Working with large volumes of this pathogen in the pilot-plant-scale pas- teurizer was considered to pose unacceptable risks to the operators. An attenuated strain of E. coli O157:H42 that had similar resistance to the most heat resistant of the 3 virulent $\mathrm{O} 157$ strains screened was therefore selected (Table 3 ).

The most heat-resistant strain chosen for each species had to be of known pathogenicity and to be biochemically typical. If the screening selected a strain of no known pathogenicity, then the most heat-resistant pathogen was chosen. For example, E. coli AE 28, an E. coli Type 1 dairy product isolate, was replaced by the attenuated O157:H42 strain. In this instance, only a marginal difference in heat resistance was observed between the 2 strains.

Three of the pathogens, Staph. aureus, E. coli, and C. sakazakii, showed a $5 \log _{10}$ or greater spread of relative heat resistances in the screening tests. The relativity found in this work is dependent on the particular combinations of time, temperature, and screening unit used. Screening under other conditions might be expected to give a similar order of strain sensitivity, but not necessarily a similar magnitude. The wide spread of resistance within E. coli and Staph. aureus illustrates the danger of using results from a single strain to repre-

Table 7. The $z$-values for the most heat-resistant pathogens of each species

\begin{tabular}{lc}
\hline Organism & $\begin{array}{c}z \text {-value } \\
\left({ }^{\circ} \mathrm{C}\right)\end{array}$ \\
\hline Staphylococcus aureus S 12 & 3.53 \\
Yersinia enterocolitica NZRM ${ }^{1} 3596$ & 2.31 \\
Escherichia coli O157:H42 (attenuated) & 3.00 \\
Cronobacter sakazakii F6-028 & 4.33 \\
Listeria monocytogenes NZRM 4237 & 2.90 \\
Salmonella ser. Typhimurium NZRM 4220 & 2.09 \\
\hline
\end{tabular}

${ }^{1}$ New Zealand Reference Culture Collection, Medical Section, Environmental and Scientific Research. 
Table 8. Extrapolated log reductions of heat inactivation curves

\begin{tabular}{|c|c|c|c|c|c|c|c|}
\hline \multirow[b]{2}{*}{ Pathogen } & \multicolumn{7}{|c|}{ Temperature $\left({ }^{\circ} \mathrm{C}\right)$} \\
\hline & 61 & 62 & 63 & 64 & 65 & 66 & 67.5 \\
\hline Staphylococcus aureus S 12 & & & & & 6.3 & 12.1 & \\
\hline Yersinia enterocolitica NZRM $^{1} 3596$ & & 7.4 & 20.0 & & & & \\
\hline Escherichia coli O157:H42 (attenuated) & & & & & 6.2 & 13.3 & \\
\hline Cronobacter sakazakii $\mathrm{F} 6-028$ & & & & & & 5.1 & 11.3 \\
\hline Listeria monocytogenes NZRM 4237 & & & & & 8.4 & 18.6 & \\
\hline Salmonella ser. Typhimurium NZRM 4220 & 9.8 & 29.4 & & & & & \\
\hline
\end{tabular}

sent the behavior of the species. These contrasted with a much more even spread with the other 3 pathogens (Figure 2). The pathogenic strains of each species were evenly spread throughout the total screened. The spread of resistances for the panel of 6 heat-resistant pathogens chosen for the pilot-plant-scale pasteurizer trials is given in Table 4 .

\section{Efficiency of Plating}

The 6 chosen pathogens were heated at 55 to $60^{\circ} \mathrm{C}$ for $30 \mathrm{~s}$ or at 60 to $62.5^{\circ} \mathrm{C}$ for $60 \mathrm{~s}$, and were plated in triplicate, with the unheated controls, on a variety of media (Table 5). The unheated samples generally showed small differences in efficiency of plating with nonselective media and the lowest recovery on a representative selective agar medium. The recovery medium showing the highest efficiency of plating at $60^{\circ} \mathrm{C}$ was chosen for the pilot-plant-scale pasteurizer experiments, unless colony size issues made a slightly lower efficiency of plating medium more practical.

Columbia base (Oxoid Ltd., Basingstoke, UK) gave the best recovery for 3 of the pathogens and a close second best for the other pathogens. The use of certain media and aerobic counting techniques may overestimate the effectiveness of heat treatment and hence the margin of safety. Cronobacter sakazakii F6-028 was the sole pathogen strain of the 6 used that showed a significant increase of $0.5 \log _{10}$ to $1.5 \log _{10}$ recovery after anaerobic incubation. Within the enterohemorrhagic $E$. coli group, sublethally stressed E. coli O157 have been reported to recover best with catalase (McCleery and Rowe, 1995) or pyruvate (Czechowicz et al., 1996) in the recovery medium. Other authors have found that these additives have little effect (Clavero et al., 1998). Anaerobic growth did not improve the recovery of the attenuated E. coli $\mathrm{O} 157: \mathrm{H} 42$ strain used in the present study. This is in contrast to a report that anaerobic growth gave a significant improvement in the recovery of heat-stressed E. coli O157:H7 (Bromberg et al., 1998). Such variations within the same group of bacteria highlight the value of working with single strains under defined conditions.

\section{Heat Inactivation Data in the Pilot-Plant-Scale Pasteurizer}

Triplicate runs for the chosen pathogens were carried out using the same batch of UHT milk for each strain (Figure 3). Because of variations in initial counts, mean $\log _{10}$ reductions were recorded. These and the temperatures of inactivation of the 6 chosen pathogens during the 15 -s treatment were Staph. aureus $>6.7$ at $66.5^{\circ} \mathrm{C}$, $Y$. enterocolitica $>6.8$ at $62.5^{\circ} \mathrm{C}$, pathogenic E. coli $>6.8$ at $65^{\circ} \mathrm{C}$, C. sakazakii $>6.7$ at $67.5^{\circ} \mathrm{C}$, L. monocytogenes $>6.9$ at $65.5^{\circ} \mathrm{C}$, and Salmonella ser. Typhimurium $>6.9$ at $61.5^{\circ} \mathrm{C}$. For Staph. aureus and C. sakazakii, the inactivation curves were extrapolated to the mean measurable limit. To exclude laboratory contamination, when only 1 or 2 colonies were detected in an undiluted sample, they were confirmed on selective agar as being the same genus as the inoculum. The $\bar{D}$-values and $z$ values for each of the chosen strains were calculated (Tables 6 and 7). A bacterial strain that is killed equally effectively under the current standard pasteurization conditions of $63^{\circ} \mathrm{C}$ for $30 \mathrm{~min}$ and $72^{\circ} \mathrm{C}$ for $15 \mathrm{~s}$ would have a $z$-value of 4.3 ; for example, C. sakazakii F6-028 with $z=4.33$. The remaining 5 pathogens with $z<4.3$ would be killed more effectively at the higher time-temperature combination.

All the pathogens reached the maximum measurable level of inactivation of $\sim 10^{7}$-fold at temperatures ranging from 61.5 to $67.5^{\circ} \mathrm{C}$. At $72^{\circ} \mathrm{C}$, the $\log _{10}$ inactivation would be substantially higher and unable to be measured directly. Attempts were made to extrapolate these first-order curves. In each case, only a few additional degrees could be considered before the confidence intervals became unrealistic. The best-fit calculation for $2^{\circ} \mathrm{C}$ above the last measured temperature is given in Table 8.

\section{Cold Shock}

Cold shock occurs when stationary phase bacteria are chilled before being heat challenged and toxic molecules form. With L. monocytogenes, for example, thermotolerance was reduced by chilling to $0^{\circ} \mathrm{C}$ (Bayles et al., 
2000). This increase in heat sensitivity results from reactive oxygen species formed during the metabolism of growing cells. These toxic products can damage injured cells, reducing the number that are able to form colonies after heating. Catalase (McCleery and Rowe, 1995) and reduced oxygen levels (George et al., 1998) can enhance the recovery of cells injured by cold shock. To minimize the effect of any cold shock and to maximize recovery of the heat treatment survivors, the inocula were not held on ice but were used as soon as harvested. Furthermore, all UHT milk for the pilot-plant-scale pasteurizer work was used at $7^{\circ} \mathrm{C}$ even though it was stored as $4^{\circ} \mathrm{C}$. This reflects the New Zealand legal requirement that milk must be cooled to $7^{\circ} \mathrm{C}$, or less, within $3 \mathrm{~h}$ of the completion of milking. Hence, $7^{\circ} \mathrm{C}$ is the temperature that pathogens, which may contaminate the raw milk supply before pasteurization, are likely to face.

\section{Modeling}

The scale-up from the SCU or other laboratory methods for generating kinetic data to heat exchangers operating under commercial conditions poses major practical issues. To obtain the time-temperature data points for the traditional determination of $D$-values, a range of different time samples at each of the chosen temperatures are taken. This raises the logistical problem of having many different holding tubes with sterilization required after each data point. More serious is the timeframe to complete the set of runs for a given strain. With our pilot-plant-scale pasteurizer, a single such experiment would be likely to take more than a week. This would introduce uncontrollable distortions in the inocula and the heating medium.

A solution to this conundrum was reported earlier (Pearce et al., 2001). By using the assumptions that hold for first-order reactions, models based solely on initial and end points were possible. Recently, Rademaker et al. (2007) used a similar approach to model the heat inactivation of MAP in raw milk. Given the experimental limitations imposed by experiments conducted with commercial-type turbulent-flow pasteurization, analysis is presently limited to the above approach.

To predict heat inactivation beyond the point at which the inoculum was completely inactivated, the best-fit equations based on the first-order parameters were used (Table 7). All the least squares models had $\mathrm{R}^{2}$ values exceeding $93.8 \%$. The poorest models were obtained for L. monocytogenes and Salmonella ser. Typhimurium. These had standard deviations of the residuals of approximately 0.2 (log decimal reduction time). It is apparent from Table 8 that meaningful prediction of heat inactivation for more than 1 or $2^{\circ} \mathrm{C}$ above the temperature at which complete inactivation was observed is not possible. That is, the inactivation achieved for these strains by standard $72^{\circ} \mathrm{C}$ for $15 \mathrm{~s}$ pasteurization is too high to be estimated with any degree of certainty.

\section{Commercial Practice}

During pasteurization in New Zealand, milk must be automatically diverted if the temperature entering the holding tube decreases to $72.5^{\circ} \mathrm{C}$. Pasteurizers are thus run with a safety margin above the divert temperature, in practice giving the milk up to 2 additional degrees of heat above the minimum legal requirement.

The heating section of the plate heat exchanger reported here had a hold-up volume of $1 \mathrm{~L}$, equivalent to $30 \mathrm{~s}$ at a pumping rate of $120 \mathrm{~L} / \mathrm{h}$. The come-down time with a 0.5 -L hold-up volume was $15 \mathrm{~s}$. These periods of increasing and decreasing temperature have lethal effects in addition to that experienced in the holding tube. Currently available commercial pasteurizers of $10,000,30,000$, and $70,000 \mathrm{~kg} / \mathrm{h}$ capacity (APV, Kolding, Denmark) have total come-up and come-down times of 42,43 , and $33 \mathrm{~s}$, slightly less than the $45 \mathrm{~s}$ of the pilot-plant-scale pasteurizer used here. The effect of increased pasteurizer size on the extent of these shoulders compared with our pilot-plant-scale pasteurizer is thus likely to be minimal.

\section{Concluding Remarks}

Simulation of commercial pasteurization conditions has allowed the key pathogen inactivation parameters to be derived for QRA models. Traditional pasteurization is the exemplar method for milk treatment. For any alternative milk treatment processes, to make informed risk management decisions on their appropriateness for health protection, it will be essential that they be compared against pasteurization as the reference point. Such risk assessment work also provides a basis for judgment of the equivalence of different food safety control measures applied to food in trade, as provided for in the WTO Sanitary-Phytosanitary and Technical Barriers to Trade Agreements (World Trade Organization, 2008). The risk analysis framework provides a scientific basis for such equivalence determinations to be established.

\section{ACKNOWLEDGMENTS}

We acknowledge the expert guidance of the Experimental Design Group: Roger Cook [Ministry of Agriculture and Forestry, Wellington, New Zealand (MAF)], Dianne Schumacher (formerly of MAF), Nigel French (Massey University, Palmerston North, New Zealand), 
Fiona Thompson-Carter (MAF), Andrew Hudson (Environmental Science and Research, Christchurch, New Zealand), and Bruce Hill [Fonterra Research Centre, Palmerston North, New Zealand (FRC)]. Equipment modifications were designed by Marcel Hollenstein (FRC). Allan Donald (FRC), the Fonterra Research Centre Workshop, and Pilot Plant staff fabricated the equipment and installed it in the $\mathrm{PC} 2$ laboratory. The skilled technical assistance of Leanne Bird, Graham Holdaway, Gordon Groube, Paul Mason, and Gary Taekema (all of FRC) is gratefully acknowledged. We thank Inez Rademacher, Euan Cant, Sally Miller, Bipan Bansal, and Peter Wiles (all of FRC) for their specialized expertise and useful discussions as well as Geoff de Lisle (AgResearch, Upper Hutt, New Zealand) and Tuan Truong (Fonterra Te Rapa, Hamilton, New Zealand). Our colleagues gave helpful criticism of the manuscript, which was edited by Claire Woodhall (FRC).

\section{REFERENCES}

Auldist, M. J., B. J. Walsh, and N. A. Thomson. 1998. Seasonal and lactational influences on bovine milk concentration in New Zealand. J. Dairy Res. 65:401-411.

Bayles, D. O., M. H. Tunick, T. A. Foglia, and A. J. Miller. 2000. Cold shock and its effect on ribosomes and thermal tolerance in Listeria monocytogenes. Appl. Environ. Microbiol. 66:4351-4355.

Bigelow, W. D. 1921. The logarithmic nature of thermal death time curves. J. Infect. Dis. 29:528-536.

Bigelow, W. D., and J. R. Esty. 1920. The thermal death point in relation to time of typical thermophilic organisms. J. Infect. Dis. 27:602-617.

Bromberg, R., S. M. George, and M. W. Peck. 1998. Oxygen sensitivity of heated cells of Escherichia coli O157:H7. J. Appl. Microbiol. 85:231-237.

Cerf, O., and R. Condron. 2006. Coxiella burnetii and milk pasteurization: An early application of the precautionary principle? Epidemiol. Infect. 134:946-951.

Clavero, M. R. S., L. R. Beuchat, and M. P. Doyle. 1998. Thermal inactivation of Escherichia coli isolated from ground beef and bovine feces, and suitability of media for enumeration. J. Food Prot. $61: 285-289$.

Codex Alimentarius. 2004. Code of Hygienic Practice for Milk and Milk Products, CAC/RCP 57-2004 (Amended 2009). Page 22. Accessed August 15, 2011. http://www.codexalimentarius.net/download/standards/10087/CXP_057e.pdf.

Codex Alimentarius Commission. 1997. Principles for the establishment and application of microbiological criteria for foods. Codex Alimentarius Commission, CAC/GL 21-1997.

Cole, M. B., and M. V. Jones. 1990. A submerged-coil heating apparatus for investigating thermal inactivation of micro-organisms. Lett. Appl. Microbiol. 11:233-235.

Czechowicz, S. M., O. Santos, and E. A. Zotolla. 1996. Recovery of thermally-stressed Escherichia coli O157:H7 by media supplemented with pyruvate. Int. J. Food Microbiol. 33:275-284.

Edelson-Mammel, S. G., and R. L. Buchanan. 2004. Thermal inactivation of Enterobacter sakazakii in rehydrated infant formula. J. Food Prot. 67:60-63.

George, S. M., L. C. C. Richardson, I. E. Pol, and M. W. Peck. 1998. Effect of oxygen concentration and redox potential on recovery of sublethally heat-damaged cells of Escherichia coli O157:H7, Salmonella enteritidis and Listeria monocytogenes. J. Appl. Microbiol. 84:903-909.

Keller, S. E., A. G. Shazer, G. J. Fleischman, S. Chirtel, N. Anderson, and J. Larkin. 2008. Modification of the submerged coil to prevent microbial carryover error in thermal death studies. J. Food Prot. 71:775-780.

Kells, H. R., and S. A. Lear. 1960. Thermal death time curve of Mycobacterium tuberculosis var. bovis in artificially infected milk. Appl. Microbiol. 8:234-236.

Kessler, H. G. 1981a. Principles of flow mechanics and residence time distributions in pipe systems. Pages 8-27 in Food Engineering and Dairy Technology. H. G. Kessler, ed. Verlag A. Kessler, Freising, Germany.

Kessler, H. G. 1981b. Pasteurization-sterilization-heating methods. Pages 139-207 in Food Engineering and Dairy Technology. H. G. Kessler, ed. Verlag A. Kessler, Freising, Germany.

Ma, L., J. L. Kornacki, G. D. Zhang, C. M. Lin, and M. P. Doyle. 2007. Development of thermal surrogate microorganisms in ground beef for in-plant critical control point validation studies. J. Food Prot. 70:952-957.

Mackey, B. M., and N. Bratchell. 1989. The heat resistance of Listeria monocytogenes. Lett. Appl. Microbiol. 9:89-94.

McCleery, D. R., and M. T. Rowe. 1995. Development of a selective plating technique for the recovery of Escherichia coli O157:H7 after heat stress. Lett. Appl. Microbiol. 21:252-256.

McClure, P., C. Stewart, M. Collins, R. Condron, I. Dumon, P. Eberhard, I. Grant, E. Komorowski, R. Lodi, M. Paris, D. Snyder, P. Tomasula, F. Varga, and S. A. Zecconi. 2004. Experimental designs. Pages 120-123 in Bulletin of the International Dairy Federation No. 392/2004, Proceedings of an International Workshop on Heat Resistance of Pathogenic Organisms. International Dairy Federation, Brussels, Belgium.

Oakley, E., L. Pearce, J. Shepherd, and S. Hathaway. 2007. Pasteurisation: Time for a reassessment? A risk assessment strategy to investigate alternative processes and technologies. Aust. J. Dairy Technol. 62:60-63.

Pearce, L. E. 2002. Bacterial diseases-The impact of milk processing to reduce risks. Pages 20-25 in Bulletin of the International Dairy Federation No. 372/2002, Proceedings of the Animal Health Conference, Auckland, 2001. International Dairy Federation, Brussels, Belgium.

Pearce, L. E. 2004. Survey of data on heat resistance of dairy pathogens. Pages 37-41 in Bulletin of the International Dairy Federation No. 392/2004, Proceedings of an International Workshop on Heat Resistance of Pathogenic Organisms. International Dairy Federation, Brussels, Belgium.

Pearce, L. E., H. T. Truong, R. A. Crawford, G. F. Yates, S. Cavaignac, and G. W. de Lisle. 2001. Effect of turbulent-flow pasteurization on survival of Mycobacterium avium ssp. paratuberculosis added to raw milk. Appl. Environ. Microbiol. 67:3964-3969.

Pearson, W. R., and D. J. Lipman. 1988. Improved tools for biological sequence comparison. Proc. Natl. Acad. Sci. USA 85:2444-2448.

Piyasena, P., S. Liou, and R. C. McKellar. 1998. Predictive modelling of inactivation of Listeria spp. in bovine milk during hightemperature short-time pasteurization. Int. J. Food Microbiol. $39: 167-173$.

Rademaker, J. L. W., M. M. M. Vissers, and M. C. te Giffel. 2007. Effective heat inactivation of Mycobacterium avium ssp. paratuberculosis in raw milk contaminated with naturally infected feces. Appl. Environ. Microbiol. 73:4185-4190.

World Trade Organization. 2008. The WTO Agreement on the Application of Sanitary and Phytosanitary Measures (SPS Agreement). Accessed May 2, 2011. http://www.wto.org/english/tratop_e/ sps_e/spsagr_e.htm. 